\title{
Politics of Hadramis: Resources Mobilization Toward Local Election in Pekalongan, Indonesia
}

\author{
David Efendi ${ }^{1}$, Suswanta ${ }^{2}$, Muhammad Lukman Khakim ${ }^{3}$ \\ ${ }^{1}$ Universitas Muhammadiyah Yogyakarta, Indonesia \\ ${ }^{2}$ Universitas Muhammadiyah Yogyakarta, Indonesia \\ ${ }^{3}$ Universitas Muhammadiyah Yogyakarta, Indonesia \\ ${ }^{1}$ Corresponding Author: defendi83@gmail.com
}

\section{Article Info \\ Keyword:}

Social capital;

Hadramis;

Electoral;

Politics.

\section{Kata Kunci:}

Modal sosial;

Hadrami;

Pemilu;

Politics.

\begin{abstract}
This paper aims to explain how to do and by what manner hadramis politics succeed in gaining influence in the local election in Pekalongan. The power of Hadrami in this city can be observed from three periods of local election in which they become the winner for city Mayor. That achievement can be easily understood due to their dominant power in religion, economics, education, civil society organization (Al Isryad), and health institution. Hadramis gained many strategic positions and had a considerable effect on society. Traditionally, Arabs lineage is identically Al Irsyad, which was affiliated with Golkar since the New Order. Also, the role of socio-economic development has become a habitus to this Arab lineage since the $19^{\text {th }}$ century. As a result, the influence of Hadrami clerics is so apparent. Therefore, the position of this Hadrami can mobilize voters quickly politically and psychologically. It became the most critical modality component to explain how Pierre Bourdieu's theory can be employed. By doing field research and doing a series of interviews in a qualitative approach, this paper aims to dig deeper to answer how the politics of Hadrami works. The findings are that the Hadrami community successfully combines modalities such as religious identity dominance, an enormous power in economic capital, social networks, and public service. Those capitals have transformed into political support toward electoral democracy. This opportunity is strongly influenced by social infrastructure as a well-established plural community. However, Hadramis itself is not a single and trustworthy entity in the political field to be so dynamic in reality toward a local election.
\end{abstract}

\begin{abstract}
Abstrak: Penelitian ini bertujuan untuk mengetahui cara bekerjanya politik hadhrami di Kota Pekalongan sehingga berhasil memperoleh dukungan hingga tiga periode berturut-turut. Capaian ini secara sederhana dapat dimengerti lantaran kekuatan modalitas keturunan Arab ini ada di segala bidang baik ekonomi, politik, keagamaan, dan pendidikan. Dengan menggunakan penelitian kualitatif dan dibantu dengan kuantitatif sebagai penambah dan penguat data. Jenis data menggunakan penelitian lapangan, observasi, wawancara berseri dengan pendekatan dan prosedur riset kualitatif. Dalam penelitian ini meskipun menggunakan data kualitatif untuk mempertajam hasil penelitian. Mengenai komunitas etnis arab di Pekalongan yang telah menjadi sebuah dominasi dalam bentuk modal sosial berupa; identitas agama, kekuatan ekonomi, jaringan sosial dan juga dalam sendi perpolitikan di Pekalongan. Berbekal dari modal sosial yang dimiliki dengan didukung kekuasaan. Kesempatan itu telah mendorong etnis Arab untuk menunjukan eksistensinya dan membentuk sebuah kekuatan baru diberbagai bidang. Meskipun begitu, kekuatan yang terbentuk tersebut didukung dengan adanya rasa kesepahaman yang solid untuk membentuk sebuah kekuatan baru terutama dalam pemilihan arah politik etnis Arab di Pekalongan khususnya Pemilukada.
\end{abstract}

Article History: Received 27-10-2020, Revised: 1-10-2020, Accepted: 25-10-2020 


\section{INTRODUCTION}

In Indonesia, the spread of Arab ethnicity has a long history as part of Vreemde Oosterling group in Indonesia. It has long settled Indonesia's territory and established a new community entity, making social integration mandatory for Indonesian citizens. Its population is the second biggest ethnic after China lineage. It is one of the ethnicities originating from outside who experienced assimilation due to stay and has long been settled since the entry of Islam in Indonesia (Soemardjan, 2008). Till1934, Arab hadramis were separated into two groups, namely 'wulaitii' and 'muwalad'. Wulaitii groups said that their land was located in Hadrami. So, they are not part of Indonesia as a nation. The muwalad group claimed that their blood is Indonesia and their nation due to marriage with local people (Haikal, 1986). Discourse on Arab, whether there are as part of nation (pribumi or non-pribumi) or not, is continued so far as the consequence of unfinished nation-state building.

The Arab community who came to the archipelago was mostly derived from Hadramaut (Berg, 2010). It is an area located on the coastline of the South Arabian region. Hadramaut's people came to the archipelago (which later became a new Indonesia in the 18th century) grew up thereafter until it reached 1.8 million. They are larger than the population in their home country, Yemen. Arabian villages are widely spread in various cities in Indonesia, for example in Jakarta (Pekojan in Jakarta, Empang in Bogor, Pasar Kliwon in Surakarta, Ampel in Surabaya, Gapura in Gresik, Jagalan di Jagalan, Kauman in some cities, Kampung Arab in Bondowoso and Banjarmasin, as well as many more scattered in other cities such as Palembang, Banda Aceh, Sigli, Medan, Lampung, Makasar, Gorontalo, Ambon, Mataram, Ampenan, Sumbawa, Dompu, Bima, Kupang, and Papua.

The relation of Islam and ethnic Arabs cannot be separated from the history of the entry and development of Islam in Indonesia. However, according to research from LWC van der Berg quoted from Alwi Sahab (2004), Traders Baghdad from Betawi stated that before 1859 there was no clear data on the number of Arabs in Indonesia. However, his research reveals that Islam does not originate from Saudi Arabia but from India (Gujarat), the Arab descendant. In Indonesia, The Arab descendants of Hadramaut generally consist of two major groups, namely Alawi and Qabili. In fact, there are people who differentiate between Alawiyyin groups who are generally followers of the organization Jamiat al-Kheir with a group of Sheikh or Masyaikh commonly called Irsyadi or followers of al-Irsyad organization. However, the second group is the majority in Pekalongan.

The phenomenon of strengthening post-reform identity politics with various variants, both the low and the high in Indonesia, also penetrated the local political constellation in Pekalongan. In Pekalongan, especially Pekalongan, the Hadrami group, or can be referred to as Arab ethnicity, has a big influence in the various real-life field of social, economics, and politics. Although Pekalongan has a heterogeneous ethnic identity such as ethnic Java, Banjar, Chinese, and Malay, Arab descent is the most prominent. Discussing Arab ethnicity, the exact data on the number of Arab ethnic populations is unclear. The ethnic political typology of Arabs in Pekalongan is able to be elucidated as a political process far from the practice of violence. In other areas, there are also a variety of local political powers in the era of electoral democracy such as the strengthening of the aristocracy and the consolidation of the old elite, the sentiments of local's men mixed with ethnicity and religiously mixed areas of men, political dynasties, informal politics, and strong local people (Klinken 2007; Augustine 2010; Hadiz 2004; Savirani 2004).

Several reasons why those studies are substantial; firstly, research on the politics of the Hadramis group in Indonesia has been discovered. It is reasonable to reckon that there are not many Arab groups involved in politics in Indonesia. Pekalongan is just a few of the hundreds of elections that illustrate the Hadramis become contestants for several periods. Unlike much Chinese ethnic literature and research work that has been widely published. Valid data related to the ethnic Arabs were classified as old data. Pekalongan, the number of ethnic in 1859 amounted to 411 persons, in 1870 increased by the number of 608 persons and in 1885 increased again to 757 persons. According to the Central Bureau of Statistics (BPS) and also the Office of Population and Civil Registration of Pekalongan City said that the estimated number of Arabs in the city of Pekalongan approximately 30,000 persons, from the population of Pekalongan that is 281,434 persons. 
The phenomenon of political involvement of Arab groups in Pekalongan is able to be regarded as a revival of an artificial political identity post-reform in Indonesia. This group's presence is considered able to take advantage of various political opportunities and democratization (election). According to Suparlan, quoted from Sri Astuti (2014) in her book entitled Kebangkitan Etnis Menuju Politik Identitas, states that identity or ethnicity is the Introduction or recognition of a person as belonging to a group based on a series of characteristics that constitute a unit of unity and comprehensive, which marks it as belonging to that class and arises and exists in interaction. Moreover, Law No.40/2008 reveals that ethnicity is a classification of human beings based on beliefs, values, norms, language, history, geography, and kinship.

Secondly, if compared with other ethnicities, their movement is absorbing that manifests one of the dominant ethnic influenced for Pekalongan society, especially in the Mayor election in Pekalongan with mobilization of social capital owned. It is due to the ethnic Arabs who have some influence on several areas such as the Religious (the role of the Habib), Education (AlIrsyad and Mahad Islam), Hospital (Siti Khodijah Hospital), some areas of the Economy (Boutique and Hotel), and other influences. This exhibits the political power of Arab descent into a significant and dynamic amid political competition and widespread political involvement in Pekalongan.

This paper aims to answer how does hadramis' modality can be transformed into political opportunity in the era of democracy, namely local election in Pekalongan. The social and economic power have been becoming a relatively established political and economic force to win the political competition. It induces the Arab ethnic influence into serious consideration for candidates who will contest in election of Pekalongan. Hence, when they are able to already obtain their influence, then the voice in the election as if also can run to them. The voter's voice seemed to be obtained through the path of the Arab background or the influence of the Habib and the donor inventory for financing campaign funds originating from Arabs.

\section{RESEARCH METHOD}

This research belongs to the qualitative research category and is assisted with quantitative as a data enhancer. The type of data using narrative research, the data obtained from the research interview will be analyzed systematically. The technique of collecting data is done by interviewing elites with some speakers such as Habib Lutfi bin Yahya, Habib Baqir bin Akhmad Al Athas, Head of Al Irsyad Pekalongan City, and business actor from Arab ethnic (Qonita Boutique). In addition, the authors also meet many different people in Pekalongan City who experience the influence of this Arab ethnicity. Some relevant sources were also taken into account for this work, such as documentation, observation, KPUD, BPS, the history of Arab ethnic and Arab ethnic movement, the data in the form of photos related to Arab ethnicity.

\section{Social Capital and Political Opportunity}

\section{RESULT AND DICUSSION}

Arab ethnics became a significant political power in Pekalongan City. This is evidenced by three times the election held, won by Arabs with various backgrounds. This certainly is able to be a common thing when the Arabs managed to win the highest political stage in Pekalongan and have succeeded in influencing the people to vote for them. In fact, both Bashir is indeed pure Arab and coupled with its representatives who are of Javanese Arab descent (Almafachir and Alex). Nonetheless, the claim that ethnic Arabs are indeed a crucial political power can be clearly illustrated by the triumphs of those three men. Especially when the couple Basyir and Almafachir who demonstrated the two figures of Arab ethnic who managed to win the competition as mayor and vice mayor of Pekalongan. It illustrates that the Arabs in Pekalongan City succeed in employing their political influence. It can be seen as three different mayoral elections:(1) The Triumph of Basyir Ahmad - Abu Almafachir (2005 - 2010). The victory of Basyir Ahmad and Abu Almafachir partner during the Pekalongan City election in 2005 were supported by Golkar and PCNU. It demonstrates one of the successful activities of Arab ethnicity in the political area, in addition to success in other fields. The presence of Basyir Ahmad of Arab ethnic background and 
Almafachir, who has a Javanese Arabic lineage, causes this candidate as one of the candidates who have great power of Arabs who emerged and won the indirect competition election selected by the people of Pekalongan City. Such a situation is certainly not necessarily the preparation by the Arabs in Pekalongan City to create a significant political power is suddenly emerged.

It has been prepared for a long time with an Al Irsyad organization. The presence of Basyir Ahmad has been prepared by himself, who had served in the Regional Leadership Council (DPD) Golkar Party that range from 1992 to 1997 and had served as Chairman of Golkar DPD in 1998. Moreover, he served as a Member of the Regional Representative Council (DPRD) Pekalongan period 1999 - 2005. He was registered as a cadre from Al Irsyad and had served as Vice Chairman of Branch Al Irsyad at Pekalongan period 1994 -1998. The presence of candidates who have mixed blood descent is absorbing to demonstrate the strength of voter support so that it is able to obtain support up to $43-45 \%$ and succeeded in winning this democratic competition; (2) The Triumph of Basyir Ahmad - Alf Arslan Djunaid (2010 - 2015). After the first period's success, Basyir Ahmad was then nominated again to become mayor of Pekalongan. However, the pair changed by selected Alf Arslan Djunaid as a pair of vice mayor. He has Djunaid family background, which is quite a significant influence, and becomes one of the characters in Pekalongan City, which is respected. Furthermore, the big name of $\mathrm{H}$. Ahmad Djunaid's father also influenced Basyir to determine Alex as his partner to win the Pekalongan City election supported by Golkar and PKS against his former Deputy Almafachir. They accomplished to win the mayor election around $53.08 \%$ of the total valid votes. The election of the pair of Bashir to Alex is behind a claim that Alex is a Javanese Arab under his great-grandfather and history of the closeness of his father $\mathrm{H}$. Ahmad Djunaid, who built the cooperative by cooperating with three ethnic entrepreneurs; Arabic, Chinese and Native. In the cooperative saving and loan known by the name of Kospin Jasa, it spread across several major cities in Indonesia. Hence, it is able to create an approach.

It is claimed that Alex is Arab Javanese. The linkage with Kospin Jasa cannot be separated from the claim because the Arabs in the establishment Kospin Jasa become a form of homage to the existence of Arab ethnic in Pekalongan. Furthermore, Pekalongan City people claims allude that Alex is semi-Arab Java or can be called Arab Javanese; (3) The Triumph of Alf Arslan Djunaid Saelani Mahfudz. In 2015, Arslan Djunaid, or familiarly called Alex, advanced to run for Mayor of Pekalongan. With the Arab-Java background, he urged his deputy, Saelani Mahfudz, from ethnic Javanese. This victory is certainly not so influential from his partner because he has the capital as Djunaid's family, which is one of the rich families of Pekalongan and some of the political history of the Djunaid family that organizes the nomination. In fact, they are supported by PDIP, PKB, PPP, PKS, Nasdem, and Hanura party. They succeed in winning the election and become Mayor and Vice Mayor of Pekalongan period 2015 - 2020 with obtaining 46.69 percent votes.

\section{Social Capital, Politics, and Democracy: Conceptualization}

In this section, it is substantial to provide a conceptual explanation of some matters relating to modalities, political participation, and democratization process that will help develop an analytical map in the next section. Firstly, the conceptualization of modality, Bourdieu (1986; see Harker 1990), and Putnam (1976) will aid in defining the theoretical realization of capital in today's political-economic or anthropological-socio-political studies as many scholars and researchers have cited. If Bourdieu much emphasizes the language and symbolic power, on the other hand, Putnam will define a lot of theory about social capital. It will be utilized by the elites as the basis of the legitimacy of action to obtain or retain power. This empirical research accommodates a variety of measurement and form of social modalities in order to response the argument from Michael Tzanakis (2013) that try to fix the indicator of social capital.

Putnam in another research on Social Connection in America with a society that develops the approach of social capital as The idea at the core of the social capital theory is extremely simple: social network matter. Network have value. We describe social Networks and the associated norm of reciprocity as social capital, because like physical and human capital, social networks create value, both individual and collective, and because we can invest in networking. Social networks are, however, not merely investment goods, for they often provide direct consumption value. 
With the theoretical concepts developed by Putnam, which in essence directs that social capital through networks and norms is a reciprocal relationship to accommodate each other, forming a valuable network of its. Thus, if implied with the existence of Arab ethnic in Pekalongan, the relationship between Al Irsyad and Golkar built through the attachment of each cadre is a form of social Network of its value as a political force in the city of Pekalongan. Social capital in Indonesia's political goods is generally associated with other modalities such as economic, cultural, and symbolic power (Efendi, 2017) to be converted into a political outcome.

With various fields controlled in Pekalongan, such as the religious through Habib's role, the economy through the various things described above. It certainly accumulates the social capital of the most powerful and big role for Arabs to widen their influences in Pekalongan. Especially in politics, which has become a significant power in Pekalongan that has been controlled by ethnic Arabs, consciously or not. Thus, the existence of ethnic Arabs will be a special calculation for the Mayor of Pekalongan Mayor. He will compete for his influence and his voice amid the political power of the ethnic Arabs themselves.

In the direct electoral system, as applied by Indonesia, at least three modalities are required as a prerequisite for a candidate to be elected. All three of them need each other, though it does not mean it will fail miserably if the lack of one of them. Lack of capital may be covered by an excess of other capital. All three are social capital, economic capital, and cultural capital. The division of capital into these three aspects refers to Bourdieu's $(1977,1986)$ theory, which attempts to comprehend how the relations of difference, power, and domination are created and maintained and how social actors operate in those relational settings. For Bourdieu, these three forms of capital elucidate the structure and dynamics of differentiated societies. In other words, the difference in access to these three modalities will greatly determine one's success in obtaining economic, social, and political opportunities.

Secondly, political participation and democracy, it is greatly common to have wide-open participation within the democratic regime. In general, political participation is the activity of a person or group of people to actively participate in political life, such as choosing a state leader that directly or indirectly influences government policy. In other opinions such as Herbert McClosky (in Budiarjo, 2008) explained, political participation would refer to those voluntary activities by which members of a society share in the selection of rules and, directly or indirectly, in the formation of public policy.

Political participation is often addressed in society volunteerism to be involved in the election of leaders either directly or indirectly. Samuel P. Huntington and Joan M. Nelson in the No Easy Choice: Political Participation in Developing Countries defines wider interpretation by explicitly incorporating illegal acts and violence in influencing a public policy process. In political participation, Milbrath and Goel, in his book Political Participation: How and Why Do People Get Involved in Politics, elucidates participation by pyramid pattern by distinguishing three categories: a. Players (Gladiators), b. Spectators, and c. Apathy (Apathetic). Arab groups in the context of Pekalongan prefer to act as Gladiators as a political rationalist.

Another approach illustrates why rational action is done. According to Huntington and Nelson, political participation can be realized from its scope and intensity in terms of size, quantity, frequency, and time. Myron Weiner provides a review of the five things that led to the movement towards wider participation in the political process; Modernization, commercialization of agriculture, industrialization, increased urbanization, the spread of literacy, improvement of education and the development of mass communication media; Changes in the social class structure; The influence of modern intellectuals and mass communication; Conflict among groups of political leaders; and widespread government involvement in socio-economic and cultural affairs (Mas'ud \& Andrew, 1982).

Finally, the political pattern of Arab descent can be grasped in the context of identity politics as one of the most crucial aspects of the study, especially in Indonesia, after the post1998 reform, where there is a widespread process of political decentralization. Substantial elements of identity can gain a highly diverse form, from the physical (e.g., skin color, hair, and eye) to the social as history, nationality, gender, ethnicity, religion, tradition, language and dialect, class and lifestyle, as well as ideology, trust and sentiment (Purwanto, 2015). Moreover, 
the intensity of identity politics is determined by one's culture and psychology (Castell in Astuti, 2014). The rise of ethnoreligious politics has also been elucidated as a transitional phenomenon (Hefner, 2001) and the involvement of Islamic-based mass organizations in the electoral process (Efendi, 2017).

Identity is a result of social construction. They generally recognize that identity is a subjective source, meaning, and experience. Therefore, it is the result of a process and social practice. Two other perspectives, such as primordialism and instrumentalist, have different views of identity. The primordial perspective recognizes that it is a marker obtained through the origin of descant and is therefore of a given nature. While the instrumentalist perspective believes that identity is the result of mobilization and manipulation. Furthermore, identity politics is grasped as a living or existing in every ethnicity. Its existence is latent and potential and can occasionally surface as a dominant political power. It is empirically an actualization of political participation organized from the cultural roots of the local society. It undergoes an ongoing internalization process within the culture of its society in a fabric of social interaction.

The strength of social modalities as the accepted Arabic identity of the local people is to illustrate a complete assimilation process. In this context, Arab descendants in Pekalongan become unfamiliar citizens. Assimilation as a socialization process between Arabs and local people will accomplish if the two communities have factors that support assimilation. These factors are the attitude of cultural tolerance, mixed marriage, and religious similarities (Kuntjoroningrat,1990). Ultimately, the modality can accomplish for this ethnic political activity.

\section{Modality and Politics as New Habitus of Arab Hadramis The Role of the Habib as Vote Getters}

The dynamics of the Arab ethnic movement in Pekalongan are quite complex. It is evidenced by his role of a certain ethnic clerics in the political arena to influence society in Pekalongan. They also seemed to compete for influence for the people. The group of the Ulama can be divided into two groups, such as the native cleric (Kyai) and the Arab cleric (Habib). Furthermore, two things that lead the axis of a struggle for influence from the Ulama, which is certainly to seize the followers (Santri). It also becomes an opportunity for candidates who will compete in the electoral process in Pekalongan. In general, Ulama is a person who is knowledgeable, especially about religion, so the population learns from him. The widespread knowledge of Islam causes Ulama to always have followers of either follower to formally attend their lectures or recitation or the Santri who live in the Islamic boarding school (Pesantren).

It makes Ulama one of the elites who have a strategic position because, in addition to his character as a figure who has extensive knowledge and deep about Islam, he also has a multitude of Santri. Thus, his command and words induce an influence on his followers. It is evidenced when the first direct election was made. Its power becomes its allure for competing for the electoral process to gain power. Moreover, of all the Ulama, the most powerful influence derives from Arab ethnic clerics, commonly called Habib.

The notion from Suparlan quoted from Sri Astuti in his book entitled Kebangkitan Etnis Menuju Politik Identitas, said that a certain identity is recognized because of its existence by others in a relationship that occurred. Based on that understanding, it appears that a person or group of people needs an identity to be used in interaction. In essence, in every interaction, someone obtains a position. Furthermore, based on that position, he performs its role in accordance with the existing style or structure of the interaction. In everyday reality, everyone will have more than one identity. That is, the more roles that run in a person's social life, then the more will be the identity of his own.

In relation to the theory with the Arab ethnic situation in Pekalongan, it is able to be clarified that in terms of social interaction exist in Pekalongan. Arabs tend to be grammatically different from the public in Pekalongan. Mixing Arabic with Indonesia and Java language, in general, renders a form of the emergence of the identity of the Arabs.

Religious influence through the role of Habib in Pekalongan certainly is not able to be denied. The influence caused to society is big enough, especially for people who participate as followers. The number of Habib in the city of Pekalongan is quite a lot and based on its 
popularity. In fact, the number of followers is classified into four Habibs, whose influence is quite considerable in Pekalongan, such as Habib Lutfi bin Yahya, Habib Baqir bin Akhmad Al Athas, Habib Ali Zainal Abidin, and Habib Abdurrahman. However, among the four Habib, the largest number of followers are Habib Lutfi bin Yahya and Habib Baqir bin Akhmad Al Athas.

They become a way for mayor candidates who will compete in the election of Pekalongan City to attract support and its influence. It is a common thing when the two Habib who have followers are desired by mayoral candidates who will advance in Pilkada.

a) Habib Lutfi bin Yahya

Maulana Al Habib Muhammad Lutfi Bin Yahya or commonly known as Habib Lutfi, is a cleric (Ulama) who was born in Pekalongan. He has the thirty-seventh lineages to the Prophet Muhammad from the father's path while the lineage of the mother has a lineage $30^{\text {th }}$ from the Prophet Muhammad. The great influence of Habib Lutfi certainly is not able to be disproved. He is the Chairman of Central Java MUI, members of Syuriyah PBNU, and Ra'is Am Jami'yah Ahlul Thariqah Al Mu'tabarah. In addition, he associates with officials in the Central Government, both ministers, and presidents. Furthermore, former President of Susilo Bambang Yudhoyono (SBY) often attended the event held by Habib Lutfi.

The presence of SBY, whose capacity as the President of Indonesia at that time certainly is not able to be considered a common thing, he was invited by Habib Lutfi at the Maulid event in Kanzuz Sholawat Pekalongan. Not only that, several times, Habib Lutfi was invited to dialogue directly with SBY at the Presidential Palace. Moreover, the closeness of the official government not only occurred in the era of President SBY. Habib Lutfi's closeness is not only arisen with former President SBY but also occurred until the era of President Jokowi. In fact, Jokowi, in his visit to Central Java, he attended the event of the Prophet's Maulidan held Habib Lutfi in the building of Kanzus Sholawat. It illustrates Habib Lutfi's closeness with officials at the national level.

He is one of Ulama in Indonesia who was invited by President Joko Widodo to meet and dialogue directly with Saudi Arabia's King Salman bin Abdul Aziz Al Saud. It arose when King Salman visited Indonesia. On that occasion, only three Indonesian ulama were given to speak directly to King Salman, such as Ma'ruf Amin, Yunahar Ilyas, and Habib Lutfi bin Yahya. They can directly dialogue with King Salman for around 30 minutes.

The many closeness of Habib Lutfi with the officials in the national government will be increasingly desired his support in the local government environment, especially Pekalongan. It certainly cannot be rebutted that every candidate of Pekalongan who will compete in elections of Pekalongan has a tradition to request approval and support from Habib Lutfi.

\section{b) Habib Baqir bin Akhmad Al Athas}

Habib Abdullah Baqir bin Akhmad Al Athas is a quite influential Ulama in Pekalongan City. He is the great-grandchild of Alm. Habib Ahmad bin Abdullah bin Tholib Al Athas, a Pekalongan Ulama who originated from Hadromaut is currently his grave in the gate graveyard of Pekalongan.

The influence of Habib Baqir's religious figure is able to be quite a consideration for the Pekalongan's mayor candidates who will compete in the elections. Nevertheless, he does not have the closeness to the national government's officials. He tends to focus more on Islamic activities as well as various religious activities both at the level of Pekalongan and surrounding areas and in the area of the district in Central Java.

He had baronial followers after Habib Lutfi. He has a mosque (Surau) which is adjacent to his house. It is a place for Habib Baqir to preach and perform various activities such as routine 'manaqiban' events, 'maulidan,' and similar events. The activity was followed by various people in Pekalongan. Even when each event will certainly make some of the ways Kyai Haji Agus Salim is crowded. It is not able to accommodate the number of followers when attending a religious event led by Habib Baqir. Such circumstances can certainly describe the number of followers who join every event held by Habib Baqir.

Regarding a large number of followers will certainly be utilized by mayor candidates who will compete in the election of Pekalongan, especially to gain sympathy from followers of Habib 
Baqir. The openness of Habib Baqir leads the candidates who will battle in the election will be easier to meet and consult the blessing of Habib Baqir.

In the above explanation and based on questionnaires submitted to 100 informants to observe the strength of Habib, it was found that the influence of Habib associated with the triumph of Pekalongan's mayor become one significant factor. Additionally, the value of influences generated about 61\%, states affected if openly four Habib (Habib Lutfi, Habib Baqir, Habib Ali, and Habib Abdurrahman) expressed support. A total of $62 \%$ said they would be influenced to follow Habib's choice. As a result, they became an influential factor in influencing voters' political preferences in Pekalongan.

By observing the number of followers and the level of popularity of each of these Habib, can be a capital of votes for the mayoral candidates to be able to gain more votes of Pekalongan people due to their sameness of religion (Islam).

\section{Resource Mobilization and Political Influence}

Their description covers many fields such as social, educational, health, and the extent of economic growth contribution in Pekalongan city. The history of this group of Arab descendants can be elucidated as follows.

a) The Role of the Al Irsyad Islamic Organization

The social organization certainly has quite a vital role concerning a cadre and ideology adopted by a group of people. In this case, the role of mass organizations, especially those directly related to Arab ethnic of Pekalongan is Al-Irsyad, which was founded on November 20, 1917, where Al Irsyad. Furthermore, the establishment of Al Irsyad branch is an area that has a community of Arab descent and also the establishment of Al Irsyad branch in Pekalongan that was established in the area of Kampung Arab Pekalongan.

One fascinating thing from Al Irsyad in Pekalongan, it has multiple roles that one of them is a social organization. The role of Al Irsyad is a manifestation of some Arabs in Pekalongan. Interestingly enough, not all Arabs join this Al Irsyad. In fact, some others joined organizations such as Nahdlatul Ulama (NU), Muhammadiyah, or other mass organizations. Thus, it demonstrates the existing Arab ethnic fusion in Pekalongan. Arab ethnic fusion that blends with the people of Pekalongan City in every activity of this life, rendering the Arabs in Pekalongan not grouped into one in an ideology in spite of the attitude has been done by some ethnic Arabs in the city of Pekalongan. Additionally, there are some others who consider exclusive to other ethnic groups.

In an interview with Chief of Al Irsyad Branch of Pekalongan clarified that social organizations like Al Irsyad are never exclusive and never differentiate from their ethnicity. The openness of Al Irsyad is inclusive that can receive for anyone to join this Al Irsyad community organization. One thing which has to comprehend is limited inclusive. It means that the person has to be a Muslim and has the same ideological view as Al Irsyad.

b) The history in the Education Field

One of the educational institutions founded by Al Irsyad is Yayasan Pendidikan Al Irsyad Kota Pekalongan located in the Al Irsyad Complex. It includes the education of pre-kindergarten, elementary, junior high, and senior high school. In this school, most of its students originate from Arab ethnicity. In addition, there are some other ethnic groups who attend the Al Irsyad School. It built and became one of the inseparable parts of Al Irsyad is certainly able to become more influential among the people of Pekalongan City where the quality of its school better than other private or state schools. However, education in Al Irsyad is quite expensive when compared with private schools in its class. Even so, do not discourage people from sending their children to this school.

In addition to Al Irsyad, there is an educational foundation run by Arabs in the city of Pekalongan called Yayasan Mahad Islam. It has several levels of education, namely PreKindergarten, elementary, junior high, and high school, similar to Al Irsyad. Similar to Al Irsyad, its students originate from ethnic Arabs in Pekalongan City. Unlike the Al Irsyad Foundation, it focuses only on the education foundation. It is not part of Al Irsyad. This is expressed directly by 
the Chief of Al Irsyad Branch. Mahad Islam (Islamic boarding school) is not organizing like Al Irsyad, who became a social organization. It is purely a foundation that is engaged in the field of education as a foundation of charitable agencies engaged in education. Founders of Mahad Islam Foundation are Abdullah Hinduan, Ahmad Assegaf, Mohammad Akbar Barakbah, and one from Javanese ethnic. In addition, Al Irsyad's relationship with Mahad Islam in terms of the foundation is certainly equally organizing in the field of education. For this reason, Mahad Islam and $\mathrm{Al}$ Irsyad are almost similar. However, Ma'had Islam only focuses on education and does not organize religious activities.

c) The Role in Health service

Regarding the health field, Arab ethnic has its own Hospital called Siti Khadijah Hospital, where the Hospital is one of the largest hospitals in Pekalongan City, among other hospitals in Pekalongan City. It became a unity within the Al Irsyad complex. In addition, it is in the management of Al Irsyad Foundation. This is quite absorbing because it resides in the same complex as the Al Irsyad Educational Foundation and the Al Irsyad Branch Office. In an interview with Said A affirmed that the management of Siti Khadijah Hospital is managed directly by Yayasan Al Irsyad of Pekalongan City. It is the largest private Hospital in Pekalongan City, which is quite fascinated by the people of Pekalongan City and surrounding areas where they need treatment. The people's trust in this Hospital is baronial with the many people's interest in using services in this Hospital.

With the explanation belabored by the informant, it is able to be comprehended about the market control of the existence of this Hospital, which became one part of an important part in the recovery of public health in Pekalongan City. The role of Arab ethnicity in Pekalongan City became the most substantial political power and has been prepared for a long time. However, not many people absorb it where initially Arabs who originate from Hadramaut came aiming to trade, preach, and seeking a new residence. It shifts with some interests and the freedom in democratizing for anyone. It is developed through social organization media such as Al Irsyad. It is a baronial in its role in shaping an ethnic Arab political power. Moreover, Al Irsyad is an epicenter of Arab politics. It is seen from the ethnic Arabs in Pekalongan City, especially those who served in the political office of Pekalongan City, which is mostly a cadre of Al Irsyad, such as Basyir Ahmad and his wife Balgis Diab.

Its important achievement is not astonishing, along with the existing democratization. They concern and spread their activity into politics to be able to accommodate their interests, especially in Al Irsyad Pekalongan City, which tends to support Golkar. It is implicitly stated by the Chairman of Al Irsyad Said Thalib related to this issue. Most of the Arabs hadramis, especially the cadres from Al Irsyad in the Golkar Party, gave the cadre the freedom to determine their political life without limitation.

Based on these circumstances, it can be absorbed as a clear finding that there is a connection between Al Irsyad Pekalongan City and Golkar Party. It is evidenced from field data stating that most Al Irsyad cadres who boast in the position of Parliament of Pekalongan City supported or derived from the Golkar Party. It elucidates there is a baronial and firm relation between Golkar and Al Irsyad in Pekalongan.

Absorbing the relations will illustrate the closeness of Al Irsyad and the social activities of Arab ethnic politics in the city of Pekalongan. Its Network is one of the powers forming a political path by holding Golkar.

d) The Role in the Economy Field

In the economic field, Arabs in Pekalongan control many businesses of the economy, such as Batik (boutique), restaurant or cafe, hotel, and textile factory. It is able to be influential in the circulation of money in the Pekalongan. In addition, the influence generated in the field of this economy can be felt by the people of Pekalongan.

There are several businesses of the economy controlled by Arabs in Pekalongan, such as:

1. Batik business includes Batik Qonita, Batik Huza, Luza Batik, Batik Toba, Batik Kuntulmas and Batik Khanan.

2. Textile Factory includes Dutatex Factory, Asaputex Factory, and Pismatex Factory. 
3. Hospitality includes Sahid Mandarin Pekalongan Hotel, Namira Hotel, and The Sidji Hotel.

4. Restaurants and Cafes include Rumah Makan Puas, Warung Oemang, Terrace Omah Tua, Ice Corner, and Orange Coffe.

On one opportunity, the author conducted an interview with the owner of Batik Qonita, which is one of the largest batik in Pekalongan. In the selection of interviews with the owner of Batik Qonita, based on the reason that the City of Pekalongan that became the icon of Batik City has a special closeness between the owner of Batik Qonita with Basyir during the campaign of Election of Pekalongan. Before Basyir served as Walikot Pekalongan, the closeness is generated due to the husband of Batik Qonita owner Gholib Hasan who also works as a doctor and colleague Basyir while working in Pekalongan hospital.

On the other hand, the closeness between Batik Qonita with Basyir Ahmad is declined by Qonita Gholib as the owner of Batik Qonita. They have never been involved in political affairs. We do not involve political practice. We are only economic actors who do business, especially in Pekalongan City (Interview with Qonita Gholib, March 28, 2017).

It is certainly different from the news that publishes that Batik Qonita participates in funding Basyir Ahmad's campaign during the elections of Pekalongan. It is certainly a common thing when entrepreneurs become one of the campaign donors, especially in several elections competition. Moreover, the renown of Batik Pekalongan is increasingly making the batik entrepreneurs will be greater when the inclusion of batik, where the current style and fashion. Thus, batik entrepreneurs will be able to develop their businesses even greater. One of the policies of Basyir Ahmad, is to hold several times an international-style batik exhibition even twice every year in Pekalongan City. It is probably organized as a form of political service from reciprocal Batik's businessmen who support it.

Various existing involvement of the Arab ethnic in the field of economy in Pekalongan can be seen from the explanation above. They who control the field of economy and become one of the machines of the economy in the city of Pekalongan create a necessity when a businessman who has emotional closeness and ethnically will give donations to candidates who are indeed one part of his identity.

Especially with the donation, it will be more flexible to accommodate the interests of the entrepreneurs. In addition, the closeness of the relationship of work and emotional connection that one of the ethnic similarities will provide a powerful influence and entrust an interest from the Arab ethnic entrepreneurs in Pekalongan.

The following chart below will illustrate how the position of modalities as the political, economic power of the Arab ethnic group in Pekalongan with the power of the modalities and Network of the Hadrami family develop a political habitat as rational choice as can be seen below.

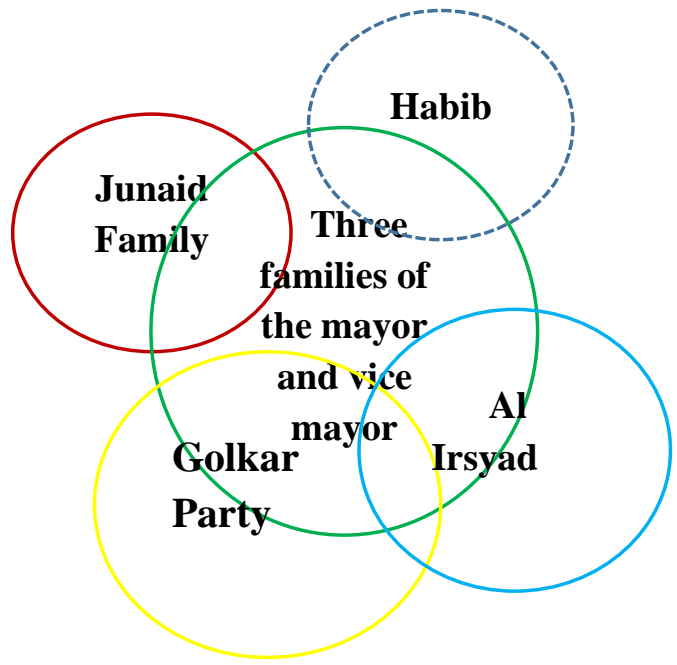

Figure.1 Political Habitus of Hadramis Family 
Pekalongan is conveyed as an area occupied by the trade sector, especially the textile industry. However, with the large number of textile businesses that serve as the foundation of the economy, Pekalongan's society is generally not interested in the field of construction or political habitus, and only a few are interested. It is able to be absorbed from the development of physical development that does not involve large construction services. In addition, certain political actors who can play its role in the political arena in various construction projects that can pass the project from the government who relate closeness to political access.

\section{e) Involvement of Arab Hadramis in Local Politics}

Alwi Sihab said that Arab Hadrami has several roles as part of Indonesia's nation in history, such as in trade, religion, and also political field (Suara Muhammadiyah, 2017). Arabs in the archipelago are involved in the political struggle of the Indonesian movement before independence or post-independence (Kwartanada, 2011). Before independence, the movement of the Arabs consists of two groups: Ar Rabitah Al Awaliyah (1928 Arab Sayid Group) and Al Irsyad (1915 Non-Arab Sayid Group). Group of Arab Sayid is Arabs who claim to be the direct descendant of the Prophet, while non-Arab Sayid group do not claim to be the Prophet's descendants. In the post-independence period, the national political movement of Arabs was associated with the establishment of the Arab Parties of Indonesia (PAI) in 1934 as 'Arab Awareness' (Baswedan, 1938). It was dissolved before the election. The figure who indeed initiated for the Arabs of Indonesia to unite and spread the first understanding of nationalism is AR. Baswedan (Grandfather of Anies Basweedan).

For the Arabs who existed in Indonesia before independence, there were many disagreements between the Arabs people who considered Indonesia only a place of shelter and people who consider Indonesia has become a country and part of life. They, especially from Hadrami, live and spread on the north coast of Java.

The role of ethnic Arabs in the economic-political movement in Pekalongan is not able to be underestimated. In some cases, many Batik entrepreneurs are from among Arab ethnic groups. They organize their role in making the Batik business, which is already characteristic of the people of Pekalongan. Furthermore, some ethnic Arabs who expand their business in the field of services such as hotel, it cannot be denied that the development of hotel is increasing every year owned by Arab ethnic businessmen. In addition, in some trends, Arabs also expand their business network in the field of restaurant or cafe. It is evident from the shift in fashion and urban people's trend of Pekalongan.

According to Klinken (2007), during the New Order transition, religious symbols are the most popular and have tremendous power to seize and retain power. Religion has long been closely linked to the rise and fall of institutions. Religious identities grew stronger in the postmilitary period in Indonesia. With an intensity that exceeds the ethnicity actively suppressed by the New Order, the religious experience is well developed but also more orthodox in middleclass circles in previous decades.

Religious politics was distributed in Indonesia as well as the circulation of radical Islamic books that became the mainstream of religious politics in Indonesia (Baswedan 2004; Bruinessen 2002, Effendy 2003; Fealy 2003). Moreover, Klinken further clarifies the story of the fragmentation of political forces in Indonesia, which is demystified as a phenomenon of consolidating the forces of ethnicity, religiosity with political constellations. Klinken reveals that Islamic political parties grew during these tumultuous reform years, exacerbating the fragmentation that has already occurred in the Islamic community and led to sectarian groups desiring to gain benefits from the situation. The most militant groups grow in this moment of charisma. They act as an instrument for one of the other political elite factions (Hasan, N.2002).

In the context of Pekalongan, the enormously dynamic social capital of Arabic descendants can be expanded to build political support and social legitimacy to perpetuate power in various areas of society. Not only illustrates the existence of the economic elite, but they also demonstrate an appealing illustration of how ethnic politics run effectively and away from the sentiment of locality in the context of the conflicting legitimacy of citizenship 
('denizenship'). The accepted patterns of cultural acculturation and daily politics are developed in several locations in Indonesia, such as Lasem, Rembang, and several cities in Kalimantan. The political acceptance of Arab groups by most Pekalongan societies indicates a strong socioeconomic acceptance. Their positive images are better than the case of a group of Chinese politics-involved in electoral competitions.

Understanding the local elite's role without seeing social modalities, cultural and symbolic capital, which is clearly transformed into political power and economic power, lead to very limited analysis and less adequate. (Smart, 2008). Savirani (2016: 417) further argues in her discover how the family of Alex as a mixed Arab descendant who became the third generation in involvement in local politics can be elucidated about his political triumph. With his political and financial issues settled and strong support from civil society, Alex secured the elements he needed to carry off what had just months earlier seemed like the unlikeliest of victories. This article has demonstrated how, in order to remain powerful, local dynastic families must shift and adapt their strategies. Over three generations, the Djunaid family had experienced highs and lows in response to external factors within the political system, the capabilities of their political competitors, and their own internal strengths and weaknesses.

The diverse accumulations of the strength of social capital supported by the educational capacity, as well as the symbolic power of the family, can be a political force. Regarding the various activities of Arab descent in Pekalongan can be elucidated as follows:

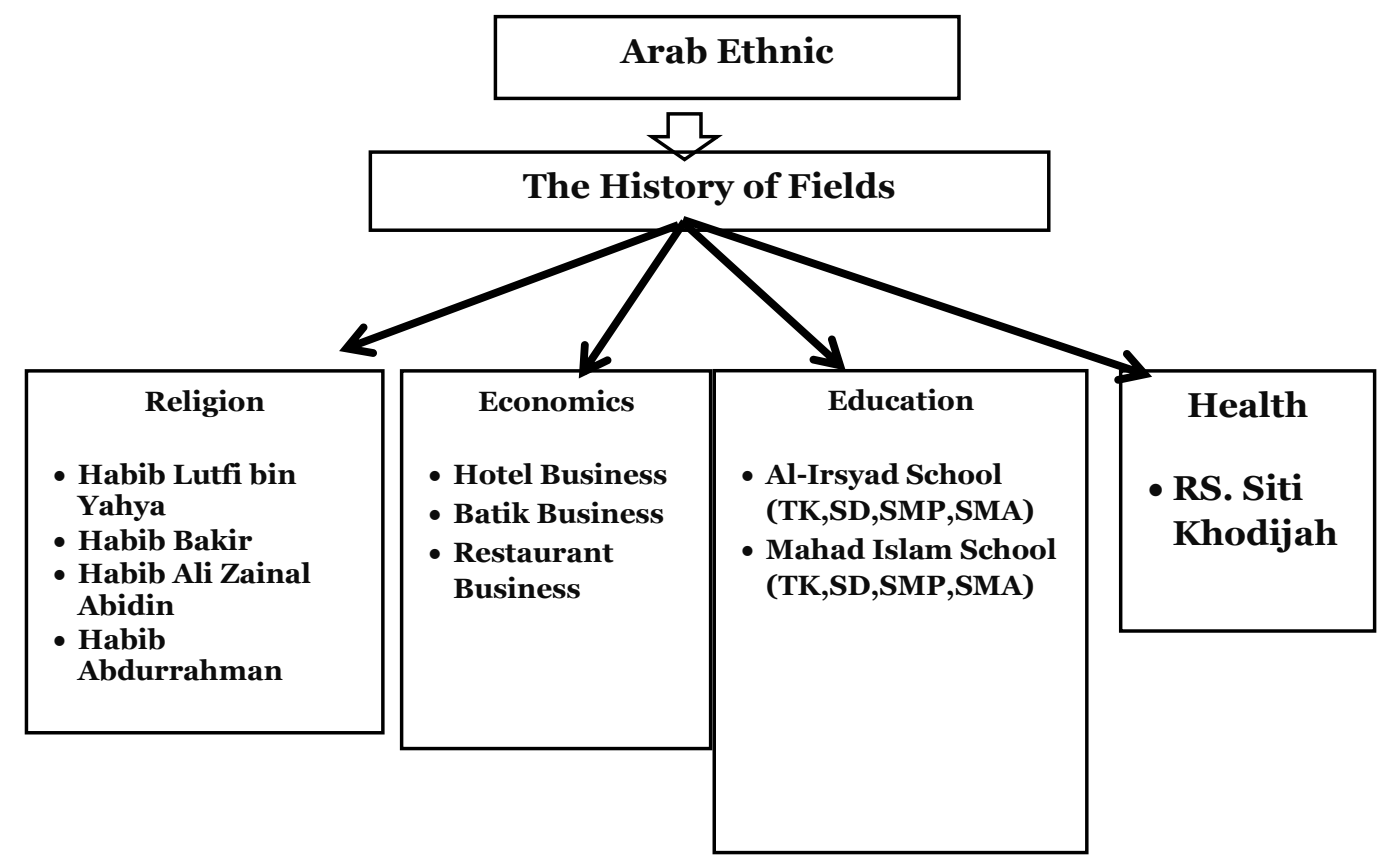

Figure.2 The Role of Hadramis Family in Pekalongan

One fascinating point illustrates that they have been politicking with the Golkar network connected to Al Irsyad in the New Order era. In this Network demonstrates the process of localization ('pribumisasi' or Indonesianisasi) of Arabs ethnic well accepted by the Islamic community. Javanese ethnic tensions with Arabs do not seem to be occurring. In fact, there is a socio-religious construction that works, that the Arabs are quite superior in the position of their spirituality.

The role of ethnic Arabs in the economic-political movement in Pekalongan is not able to be underestimated. In some cases, many Batik entrepreneurs are from among Arab ethnic groups. They organize their role in making the Batik business, which is already characteristic of the people of Pekalongan. Furthermore, some ethnic Arabs who expand their business in the field of services such as hotel, it cannot be denied that the development of hotel is increasing every year owned by Arab ethnic businessmen. In addition, in some trends, Arabs also expand 
their business network in the field of restaurant or cafe. It is evident from the shift in fashion and urban people's trend of Pekalongan. It illustrates that Arab Hadramis as 'the ruling elite' is not always can be understood in the conflictual as Bourdieu's contribution, but they succeed in making good social integration because of Islam religion. This is in line with Loïc Wacquant's (2013) argument in his study on Bourdieu in which he problematized the existence, boundaries, and degree of cohesion of both superordinate and subordinate class, and he opens up for empirical inquiry the social modalities of their possible unification and eventual capacity for joint action."

\section{CONCLUSION}

The existence of Arab ethnic elites is an influential political power in the Pekalongan. It is evidenced by the triumph of candidates of Arab descent in the three periods of an election in this city. Some of the elite of the Arabs, among others Basyir and who had been his vice mayor Almafachir and Alex, managed to win the election mayor two periods. He is a descendant of the political family of the Djuniad family, who made Alex learn a lot about politics, especially ethnic politics. Furthermore, Alex is half the Arab blood managed to seize the triumph of Pekalongan mayor in 2015. Organization Al Irsyad is a political machine that became the political epicenter of the Arabs. Apart from being entrepreneurs, the Arab group or al Irsyad cadres served in various structural positions in the DPRD of Pekalongan and structural positions in the Golkar Party. The closeness of Al Irsyad with Golkar is a power relation built since and post the New Order period. Golkar has been a political habitus of Hadramis.

Not surprisingly, along with the democratization in Indonesia through direct election to elect the mayor, including the mayor of Pekalongan, render the history of the Arabs expanded their business from the beginning of trading, preaching, discovering for a place into social acceptance (Walker, 2012: 15-15). They initiate to expand to various fields, including politics, as described above. In addition, other fields are expanded by Arabs in the Pekalongan. In the economic field, ethnic Arabs have more established economic strength. It is evidenced by several types of economic fields controlled by them, which later could become one of the instruments of a political movement with the donation of the businessmen from the Arab ethnic. It can certainly be motivated by interests that exist in the entrepreneurs, the similarity as ethnic Arab descent, or because of emotional or personal closeness. However, the most substantial is about the interests that will be organized from the major candidate to the entrepreneurs.

In the social approach, the Arab descendants of Pekalongan occupy a substantial position, especially with a figure like Habib Lutfi, more inclusive that can be accepted by society. Both the concepts delivered are more acceptable to all communities and not a threat when compared with some of the exclusive religious leaders and not compatible with the local culture. Moreover, the existence of Habib Baqir, Habib Ali, and Habib Abdurrahman is widely accepted by the people of Pekalongan. They can influence the political choices of the people of Pekalongan. In addition, changes in social structure and the opening of political opportunities in Indonesia, such as the Arab ethnic group in Pekalongan, began to penetrate the new habitus of politics where it has transformed the limitations of movement that originally toward the activities of Islam preach, trade, and play a role in social economy activity.

\section{ACKNOWLEDGEMENT}

The authors owe to many people in Pekalongan, informants, a family of Hadramis, and many others who gave us meaningful information in order to make possible this research accomplished. Thanks to the Department of Governmental studies and also Universitas Muhammadiyah Yogyakarta for the funding and resources for this study.

\section{REFERENCE}

Afriani, Risna dan Dyah Kumalasari. Lembaga Pendidikan Al Irsyad Al Islamiyyah Pekalongan Dalam Penanaman Nasionalisme Keturunan Arab Tahun 1918 -1942. Jurnal Student, (Online), 
(http://journal.student.uny.ac.id/ojs/index.php/risalah/article/viewFile/1865/1599, di akses 5 April 2017).

Agustinus L (2010) Dinasti Politik pasca-otonomi Orde Baru: Pengalaman Banten. Prisma 29(3): 102-116.

Astuti, Sri Buchari. 2014. Kebangkitan Etnis Menuju Politik Identitas. Jakarta: Pustaka Obor.

Akhsin, Naim Hendri. 2011. Sensus Penduduk 2010. Jakarta: Badan Pusat Statistik.

Algadri,Hamid. 1983. C. Snouck Hurgronje Politik Belanda terhadap Islam dan Keturunan Arab. Jakarta: Sinar Harapan.

Bahafdullah, H.A. Madjid Hasan. 2010. Dari Nabi Nuh Alaihissalam Sampai Orang Hadhramaut di Indonesia: Menelusuri Asal Usul Hadharim. Jakarta: Bania Publishing.

Basweda, AR. 1938. 'Ampat Oktober: Ringkasan Khotbah Hari Kesadaran 1938'. Dalam majalah Aliran Baru nomor edisi 3 Oktober 1938 halaman 52-53 diakses dari http://nuun.id/ikrar-keturunan-arab-jadi-bangsa-indonesia tanggal 12 Oktober 2017 pukul 07.20 WIB.

Berg, W. G. Van Den. 2010. Orang Arab di Nusantara. Jakarta: Komunitas Bambu.

Budiarjo, Miriam. 2008. Dasar-Dasar ilmu Politik. Jakarta: Gramedia.

Dirhamsyah, M. 2014. Pekalongan Yang Terlupakan. Pekalongan: Kantor Perpustakaan dan Arsip Daerah Kota Pekalongan.

Efendi, David. 2017. Muhammadiyah dan Piplres: Wahana Pendidikan Demokrasi Bagi Civil Society. Yogyakarta: Simpang.

Fathurahman dan Sobari. 2004. Pengantar Ilmu Politik. Malang: UMM Press.

Hadiz VR (2004) Indonesian local party politics: A site of resistance to neoliberal reform. Critical Asian Studies 36(4): 615-636.

Hayaze, Nabiel A Kariem. 2015. A.R. Baswedan: revolusi Batin sang Perintis. Bandung: Penerbit Mizan.

Harker, Richard et al., 1990. The Introduction to the work of Pierre Bourdieu: The Practice Theory. London: McMillan Press Ltd.

Hefner, Robert W, Civil Islam: Islam dan Demokratisasi di Indonesia. Jakarta: ISAI dan TAF, 2001.

Husain Haikal, "Indonesia-Arab dalam Pergerakan Kemerdekaan Indonesia 1900-1942", disertasi Universitas Indonesia, 1986, hal 75-100)

Kinasih, Dian. 2013. Interaksi Masyarakat Keturunan Arab Dengan Masyarakat Setempat Di Pekalongan. Jurnal Komunitas, (Online), Vol. V. No.1 Maret 2013: 38-52 (http://journal.unnes.ac.id, di akses 5 Oktober 2016).

Klinken, Geery V.2007.Perang Kota Kecil, Kekerasan Komunal dan Demokratisasi di Indonesia. Jakarta: YOI.

Koentjaraningrat. 1990. Pengantar Ilmu Antropologi. Jakarta: PT Rineka Cipta.

Koesnaedi, Hery. 2014. Menulis Skripsi, Tesis \& Disertasi. Yogyakarta: Araska.

Kwartanada, Didi. 2011. Dari "Timur Asing" ke "Orang Indonesia": Pemuda Tionghoa dan Arab dalam Pergerakan Nasional (1900-1942), dalam jurnal PRISMA volume 30 no 2 (2011), GERAKAN PEMUDA 1926-2011: Persatuan Terhenti, Kesatuan Asimetris. Halaman 41-54.

Mujani, Saiful. 2007. Muslim Demokrat, Islam Budaya Demokrasi Dan Partisipasi Politik di Indonesia Pasca Orde Baru. Jakarta: Gramedia.

Mas'ud, Mochtar., Colin Mac Andrew. 1982. Perbandingan Sistem Politik. Yogykarta: UGM Press.

Muhibbin. 2012. Politik Kiai Politik Rakyat. Yogyakarta: Pustaka Pelajar.

Mat,Farid Zain dan Nurul Wahidah F. 2014.Ulama Arab di Tanah Melayu : Satu Analisa Pada Awal Abad Ke-20.Jurnal Religi, (Online),Vol.X No.2 184-203. (http://www.uinsuka.ac.id, di akses 5 Oktober 2016).

Noer, Deliar. 1982. Gerakan Modern Islam di Indonesia 1900-1942. Jakarta: LP3ES.

Nur, Bahdin Tanjung dan Ardial. 2005. Pedoman Penulisan Karya Ilmiah. Jakarta: Kencana.

Purwanto. Politik Identitas dan Resolusi Konflik Transformatif. Jurnal Review Politik. Vol VI. No. 01 Juni 2015: 63 - 64 (http://www.ejournal.uinsby.ac.id).

Putnam, Robert. 2002. Democracies in Flux: The Evolution of Social Capital in Contemporary Society. New York: Oxford University Press. Inc 
Rudi Salaman Sinaga. Pemasaran Politik Basyir Pada Pemilihan Umum Kepala Daerah Kota Pekalongan Tahun 2010. Jurnal Perspektif / Volume 6/Nomor 1/April 2013. ISSN 2085 0328 (ojs.uma.ac.id/index.php/perspektif di akses 11 Mei 2017)

Savirani, A. 2016. Penolakan Terhadap Reformasi: Kekuatan cengkeraman Patrimniaslisme di sektor Konstruksi di Pekalongan, dalam buku In search of Middle Indonesia: kelas Menengah di Kota-Kota Menengah (Jakarta: Buku Obor, 2016), hal. 169-182.

Savirani, A., 2016. Survival against the odds: The Djunaid family of Pekalongan, Central Java. Southeast Asia Research, Vol. 24(3) 407-419

Savirani, A. (2004) "Local Strongman in New Regional Politics in Indonesia," Master's thesis submitted to International School of Humanities and Social Science, University of Amsterdam.

Sahab, Alwi. 2004. Saudagar Baghdad dari Betawi. Jakarta: Republika.

Smart, Alan. 2008. Social Capital. Anthropologica, Vol. 50, No. 2 (2008), pp. 409-416

Soemardjan, Selo. 2008. Steriotip Etnik, Asimilasi, Integrasi Sosial. Jakarta: Pustaka Grafika Kita

Sugiyono. 2010. Metode Penelitian Kuantiatif, Kualitatif dan R\&D. Bandung: Alfabeta.

Tzanakis, Michael, 2013. Social capital in Bourdieu's, Coleman's and Putnam's theory: empirical evidence and emergent measurement issues Educate Vol. 13, No. 2, 2013, p. 2-23.

Wacquant, Loic. 2013. Symbolic power and group-making: On Pierre Bourdieu's reframing of class. Journal of Classical Sociology 0(0) 1-18.

Walker, Lain. 2012. Comorians and Hadramis in the western Indian Ocean: diasporic practices in a comparative context. Journal of Social Dynamics, 2012, 38 (3): 435-453. Available at http://www.tandfonline.com/doi/abs/10.1080/02533952.2012.756722\#

Website :

KPU Kota Pekalongan. (http://www.ppid.kpu.go.id, di akses 11 Oktober 2016).

Suharto, Edi Modal Sosial dan Kebijakan Publik. Artikel dari web http://www.policy.hu/suharot/naskahpdf.html. di akses pada 1 November 2016.

https://kampoengampel.com/berita/sejarah/2-sumpah-pemuda-keturunan-arab.pdf diunduh pada tanggal 06 Oktober 2017 pukul 15.30 .

https://alwishahab.wordpress.com/2009/08/05/partai-arab-indonesia/ diunduh pada tanggal 07 Oktober 2017 pukul 15.50

Isabelle Breuskin. Social Capital and Governmental Institutions. Artikel dari web http ://www.ethz.ch/workingpapers/living_review_democracy/breuskin.pdf. di akses pada 11 Mei 2017.

Kospin Jasa. Sejarah. http://www.kospinjasasyariah.com/sejarah, di akses pada tanggal 11 Mei 2017 pukul 08.30

Suara Merdeka. Empat Putra Terbaik Siap Dipilih. Koran Online Suara Merdeka 2005. Di akses dari http://www.suaramerdeka/harian.0506/002/pan04.html, pada tanggal 1 November 2016 pukul 21.00.

Badan Pusat Statistik Kota Pekalongan 2010. (http://www.pekalongankota.bps.go.id)

Serambi Islami. Habib Lutfi Hadiahkan Serban Ijo Buat SBY. diakses dari http://www. Serambiislam.com/54/81/00/habib-lutfi-hadiahkan-serban-ijo-buat-sby.htm, di akses pada tanggal 1 April 2017 pukul 16.30.

Detik News. Jokowi Peringati Maulid Nabi Bersama Habib Lutfi di Pekalongan diakses dari http://news.detik.com/berita/3390388/jokowi-peringati-maulid-nabi-bersama-habiblutfi-di-pekalongan, di akses pada 2 April 2017 Pukul 17.30

Suara Merdeka. Minta Masukan Luhut Silaturahmi Ke Habib Lutfi. diakses dari http://berita.suaramerdeka.com/smcetak/minta-masukan-luhut-silaturahmi-ke-habibluthfi, di akses pada 2 April 2017 Pukul 18.37

Suara Muhammadiyah. 2017. Peran kebangsaan keturunan Arab di Indonesia. Edisi 16-30 September 2017

Kompas. Raja Salman Temui Tokoh Agama Islam di Istana, Ini Yang Dibicarakan, diakses dari http://nasional.kompas.com/read/2017/03/02/18335001/raja.salman.temui.tokoh.aga ma.islam.di.istana.ini.yang.dibicarakan, di akses pada 2 April 2017 Pukul 19.30 
Tempo. Dukungan Habib Lutfi Tak Dongkrak Suara Prabowo, diakses dari https://m.tempo.co/read/news/2014/07/10/078592122/dukungan-habib-lutfi-takdongkrak-suara-prabowo, di akses pada 4 April 2017 Pukul 12.49.

Al Irsyad. Tentang Al Irsyad. diakses dari http://alirsyad.net/tentang-al-irsyad/ , di akses pada 5 April 2017 Pukul 17.27

Kompas Com. Cermin Berjuta Wajah di Pekalongan. http://travel.kompas.com/read/2016/06/23/073300927/Cermin.Berjuta.Wajah.di.Pekal ongan, di akses pada tanggal 11 Mei 2017 pukul 10.00

Detik News. Suara Di Bawah 50 Calon Golkar NU Pimpim Kota Pekalongan. Diakses dari http://news.detik.com/berita/376483/suara-di-bawah-50-calon-golkar--nu-pimpinkota-pekalongan, di akses pada tanggal 11 Mei 2017 Pukul 05.30.

\section{Regulations/laws:}

Undang-Undang No 40 Tahun 2008 Tentang Penghapusan Diskirminasi Ras dan Etnis.

UU No 29 Tahun 1999 Tentang Penghapusan Segala Bentuk Diskriminasi Rasial.

Undang-Undang Nomor 32 Tahun 2004 Tentang Pemerintah Daerah.

Undang Nomer 16 Tahun 1950 tanggal 14 Agustus 1950 Tentang Pembentukan Daerah Kota Besar Dalam Lingkungan Jawa Barat/Jawa Tengah/Jawa Timur dan Daerah Istimewa Jogjakarta.

Undang-Undang Nomor 18 Tahun 1965 tentang Pokok-Pokok Pemerintahan Daerah, maka Pekalongan berubah sebutannya menjadi Kotamadya Dati II Pekalongan.

PP Nomer 22 Tahun 1999 tentang Pemerintahan Daerah

Interviews:

Interview with Qonita Gholib (Owner of Qonita Batik). March 28, 2017

Interview with Habib Lutfi bin Yahya. March 15, 2017

Interview with Habib Baqir bin Akhmad Al Athas, April 4, 2017

Interview with Sultan Tebe, April 20, 2017 